\title{
What Did Jesus Write on the Ground? Exegetical Analysis of John 8: 6-8
}

\author{
Milan Kostrešević \\ Faculty of Theology of the University of Bern \\ milan.kostresevic@gmail.com \\ https://orcid.org/0000-0002-6356-5944
}

\begin{abstract}
Inspired by a sermon by Saint Nicholai of Ohrid and Ziča on Jesus' writing on the ground, the paper offers an insight into a wide range of exegetical analyses concerning the three basic issues related to Jesus' writing on the ground presented in John 8: 6-8. The question of the content of the inscription is first investigated. Despite the complete absence of the actual text, numerous authors over time have made many possible but hypothetical suggestions as to what words Jesus could have written. Then, various suggestions are considered regarding the meaning of this action, that is, the very fact that Jesus wrote. Finally, the study deals with the question of Jesus' literacy and in connection with Keith's claim that this pericope is a third-century interpolation inserted into the text of the Fourth Gospel in order to satisfy the Church's needs for literate leaders.
\end{abstract}

Key words: Writing on the ground, historical Jesus, sinful woman, literacy, Decalogue, pericope adulterae, Nicholai Velimirovich.

In the works of the pagan priest from Delphi, historian and member of the middle Platonism Plutarch from Chaeronea, there is, among other things, the story of Antigonus the First Monophthalmos (one-eyed), who lost an eye during the siege of Perinthos (around $340 \mathrm{BC}$ ). He was hit by a catapult bolt. In the same story (Mor. 183), Plutarch talks about the practice of writing on the ground, suggesting that it was carried out when a certain member of society was not allowed to speak in public. 
The story of a woman caught in adultery (John 7: $53-8: 11$ ), known in the New Testament scholarship as the pericope adulterae, which also gives us a description of Jesus' act of writing on the ground, has experienced an impressive number of studies in the history of New Testament exegesis. The research presented in them mainly concentrates on two basic issues: the origin and reception of the pericope, the date of its origin (together with its presence or absence in ancient manuscripts), ${ }^{1}$ and its correct interpretation (Keith 2008, 377-404). Among the many studies dedicated to this pericope, there are those that concentrate only on the very act of writing on the ground. Since this is the only place in the entire canonical and noncanonical biblical literature about Jesus as a writer, the interest in this element is understandable. Augustine of Hippo included in his works at least six different explanations of Jesus' actions as a writer, repeating the solutions of Ambrose of Milan and Jerome of Stridon, and adding his own (Knust 2006, 533). ${ }^{2}$ Chris Keith has already calculated thirty-eight interpre-

${ }^{1}$ There is a consensus among contemporary researchers of the John's Corpus regarding the status of this pericope as a subsequent interpolation in relation to the remaining text of the Fourth Gospel. The current location of the pericope after John 7: 52 was also the most popular over the centuries. There are, however, manuscripts in which this pericope is found after Lk. 21: 38 (on the linguistic level there is a similarity between Lk. $21: 37-38$ and Jn. 8: 1-2) or as an addition to the entire John's Gospel after John 21:24 considering the criterion of compatibility of the text of the pericope with the literary context in which it appears, the best candidate for the original or original context is the text of Jn. 7-8. See more in: Keith 2009a, 209-231.

${ }^{2}$ In the history of the reception of the Gospel of John, it will be noted that the Latin fathers, to whom we refer in this study, paid much more attention to this pericope than their Greek contemporaries. Greek commentators have been devoting themselves to this pericope only since the 12th century. However, Eusebius suggests that Papius of Hierapolis knew the passage as part of the Gospel of the Jews (Historia Ecclesiastica III, 39,17). In the works of John Chrysostom known today, paragraphs 7: $53-8,11$ are not quoted. However, the Catholic preacher Jacobus de Varagine (13th century) claims: "and, according to John Chrysostom, he wrote: 'Ground, swallow these rejected people." (Hevelone 2010, 54). It is currently unknown whether Jacob confused the name of John Chrysostom with someone else, or whether there really was a work that has not been preserved to this day. In the East, the first interpretation of the passage belongs to Euthymius Zigabenus in the twelfth century. 
tations and himself added his thirty-ninth attempt to answer the meaning of this act. Interpretations that try to explain Jesus' act go in two main directions. Such a considerable number of commentators consider the content of the inscription. These are inherently hypothetical considerations, because the author of the pericope did not provide us with any information regarding the content of the inscription. Other commentators choose a safer path, focusing on the fact and motif of writing. One possible answer is a suggestion that is almost completely banal, seeing in Jesus' activity proof of his literacy. This answer presupposes another, fundamental question posed in contemporary research of the historical Jesus, namely the question of Jesus' literacy. The three problems mentioned above will be the subject of our study. We will first present the opinions of the exegetes on the hypothetical content of the inscription of Jesus. Next, we sketch the different motifs for which Jesus wrote on the ground, pointing to the most convincing proposal. Finally, without delving into the purely historical question of Jesus' literacy, we will touch on this problem in his relationship with adulterers.

\section{Reconstruction of the content of the inscription}

Although the text of John's Gospel says nothing about the content of the inscription that Jesus was supposed to make, many exegetes, starting with Ambrose of Milan, offer five tried and tested solutions, and as a review of contemporary commentary shows, they are still trying to identify this content. The proposals go mainly in three directions. It most often refers to intertextuality, i.e. it is claimed that Jesus wrote some fragment or fragments of the Old Testament. Equally popular is the claim that Jesus wrote a sentence that incriminates a woman and, paradoxically, liberates her at the same time. The third suggestion that often appears is Jesus' statement in John 8: 7. 


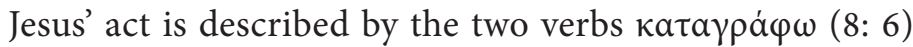
and $\gamma \rho \alpha \dot{\varphi} \varphi \omega(8: 8) .{ }^{3}$ Both verbs express the act of writing in their basic meaning. The first of these, present already in Jb. 13, $26 \mathrm{LXX}$; as in ancient papyri ${ }^{4}$, it can be translated as write down, register, record. Because of this, many commentators in ancient times believed that Jesus had begun to compile a list of sins. This interpretation also appeared in some ancient Greek and Armenian manuscripts. ${ }^{5}$

The Book of the Prophet Jeremiah was often mentioned in the above suggestions in connection with the writing of sinners on the ground: "O Jehovah, the hope of Israel, all that forsake thee shall be put to shame. They that depart from me shall be writ-

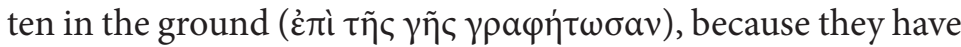
forsaken Jehovah, the fountain of living waters" (Jer. 17: 13) The text itself does not speak directly about sins, but the mention of those who leave God identifies them as sinners par excellence. The spiritual leaders of people who accuse a woman of adultery are in fact spiritual adulterers, because, as the prophet Jeremiah says, they oppose the provisions of the covenant and follow other gods. The main example of interpretation that sees the list of sins as the content of Jesus is the work of Jerome, Dialogue against the Pelagians. Jerome, quoting the prophecy of Jeremiah above, says that Jesus wrote the sins of the accusers and all

\footnotetext{
${ }^{3} \mathrm{~V}$. Tatalović $(2019,137)$, pointing to the frequent use of the verb $\gamma \rho a \dot{\varphi} \varphi \omega$ in the fourth Gospel, claims that "with this use, which reflects the authority of the Old Testament, the Gospel is in agreement with other New Testament books, to which the statement that Christ is fulfillment $(\pi \lambda \eta \rho$ ó $\omega)$... and the end ( $\tau \varepsilon \lambda \varepsilon \iota \dot{\omega} \omega)$ of the Scriptures."

${ }^{4}$ For example: P.Oxy. 327 as well as P.Oxy. 472.

${ }^{5}$ Several Greek manuscripts (UP and then 73, 364, 782 and 1592) add the follow-

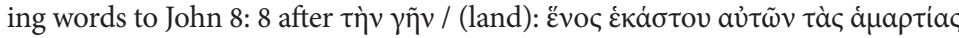
Codex 264 (12th century) sets this voice after $\tau \grave{\eta} v \gamma \tilde{\eta}$ in Jn 8: 6. The oldest two codices mentioned here $(\mathrm{U}, \mathrm{P})$ date from the 8 th or 9 th century. This diversity is also noticeable in Armenian manuscripts. See: Metzger 2001, 190. The Armenian text of this pericope is in the codex from 989. It contains the following sentences: "He bowed his head and wrote with his finger on the ground to announce their sins. And they saw their many personal sins on the stones." More in: Conybeare 1895, 406.
} 
the people of the ground: they leave it on the ground to be written." (Adv. Pel. 2,17,20-23).

The interpretation relating to Jer. 17: 13 can be understood in four ways:

(1) As is the case in Jerome's statement quoted above, it is a record of $\sin .^{6}$

(2) The Latin Fathers of the Church (Ambrose, Augustine, Jerome) claim that Jesus wrote the names of the prosecutors. ${ }^{7}$

(3) Jesus could only write the words of prophecy Jer. 17: 13.

(4) Jesus performed a prophetic act, that is, he made a gesture of writing (without writing any specific content) and directing the course of events (mentioning sins in Jn. 8: 7), he actually implemented this prophecy (Michaels 2010, 497). ${ }^{8}$

\footnotetext{
${ }^{6}$ Augustine almost quotes Jerome (Pelag. 2:17), adopting his interpretation by referring to Jer 17: 13 and identifying Jesus' opponents as sinners saved on ground: "All those who forsake you may be ashamed; can those who retreat across the country be written off? It will be clear that Jesus marked these, because the Jews, defeated and confused, when they heard: 'He who is without $\sin$, let him be the first to throw a stone at her', one after the other withdrew. It was then that he showed from which number, writing with his finger on the ground." More in: Knust 2006, 517-519.

${ }^{7}$ Ambrose, Epistle 50: 5: "While the Jews were praying, the names of the Jews were written on the ground, and since the Christians came, the names of the faithful are not written on the ground but in heaven. Therefore, those who were rejected by their Father, who tempt the Father and insult the bringer of salvation, are written on ground" (CSEL 82, 58). Ambrose clearly refers to Jer. 17:13: "All who forsake you will be ashamed, and those who withdraw will be written on the ground." According to Augustine (De cons. Ev. 4,10,17), Jesus began to write on ground to indicate to the accusers that they deserved to be inscribed on ground, unlike the disciples whose names were joyfully written in heaven: "When he wrote with his finger, on ground, he showed them as such (i.e. as they really are) by writing [their names] on ground and not in heaven" (CSEL 43,411). Ambrose has already presented the same parable (Epistle 68:14): "Sinners (i.e. their names) are written on the ground, and the righteous in heaven, as you have [written] that he said to his disciples: 'Beware, for the names are yours written in heaven."

${ }^{8}$ According to some exegetes, the connection between Jesus' activities (who bends and writes on the ground) and Jer. 17:13 was so evident that Jesus did not have to write down a certain content; he could write anything. Up. Beasley-Murray 1999, 146; Whitacre 1999, 207.
} 
Modern exegetes often combined the second and third propositions. Jesus first wrote the words of the prophecy from Jer. 17: 13. Jesus' opponents, however, did not understand the message of the prophecy. Then, bending over again, Jesus wrote down the names of the accusers (Whitacre 1999, 208). H. J. Toensing, combining the first and second propositions, sees in the first Jesus inscription a record of all the other acts condemned by the law (and thus for the sins that accuse the plaintiffs), while in the second he notes the moment when Jesus addressed the prosecutors, saying that "other acts" refer to them (Toensing 2003, 164-165). Many modern commentators consider the interpretation of Jer. 17: 13 to be the most convincing. ${ }^{9}$ Referring to this prophecy, Jesus would refer to the idea of God's judgment on sinful Israel. In the presence of God, all people are sinners and as such have no right to judge others.

Rudolf Schnackenburg believes that the allusion to Jer. 17: 13 corresponds to the development of the plot in the entire pericope. People sensitive to prophetic signs, such as women accusers who were familiar with the Scriptures, could easily read the connection between the words of the prophecy and the situation in which they found themselves. If they did not see this connection, Jesus explained it in his own words (Jn. 8: 7). Continuing to write prophecy, Jesus forced them to confess their sinfulness (Schnackenburg 1990, 165). Michael Theobald emphasizes the importance of the structure of the pericope in which two references to the writer Jesus (8: 6.8) form the framework for Jesus' words in 8: 7. Therefore, since Jesus' word is about sin, his act of writing should point to the same reality (Theobald 2009, 558). The interpretation relating to Jer. 17: 13 also has support in the immediate literary context of both John's text and the prophecies, as both contexts speak of the temple (Jer. 17: 12; Jn. 7-8) and the desire to drink water (Jer. 17: 5-7; Jn. 7: 37-38). Just as God identified himself with the source of living water $(\pi \eta \gamma \eta े$

\footnotetext{
${ }^{9}$ For more details see: Eisler 1923, 306-307; Jeremias 19626 ${ }^{6}$ 226; McDonald 1995, 421; Wilckens, 2000, 139; Schnelle 20094, 168; Theobald 2009, 558.
} 
$\zeta \omega \tilde{\eta} \varsigma$ / Jer. 17: 13), Jesus identifies himself with "rivers of living

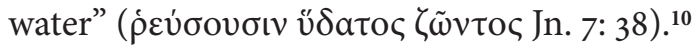

The objection raised against this interpretation is doubt as to whether the reference to Jer. 17: 13 was so obvious to Jesus' opponents and whether it was also obvious to the readers of the fourth Gospel (Schnackenburg 1990, 165). According to Theobald, the Judeo-Christian reader of the pericope (the original recipient of the text) was certainly familiar with the prophecy of Jer. 17:13 and could easily interpret it (Theobald 2009, 558). ${ }^{11}$ However, as patristic and contemporary commentaries show, Jesus' act of writing is also read as an allusion to other Old Testament texts. Furthermore, the interpretation that signifies Jer. 17: 13 as the original text omits an important detail of John's text, and that is the use of the finger to write on the ground.

Ambrose of Milan thus claims in one of his letters (Epistle 50.4) that Jesus wrote the words, "Ground, ground, write down these rejected people, as it is written for Jehoniah in the prophet Jeremiah." However, the text that Jesus would suggest with his inscription is Jer. 22: 29-30: "O ground, ground, ground, hear the word of Jehovah. Thus saith Jehovah, Write ye this man childless, a man that shall not prosper in his days; for no more shall a man of his seed prosper, sitting upon the throne of David, and ruling in Judah." A possible echo of this quote are the words terra terram accusat ("the ground accuses the ground"), which are found by voice in the $\mathrm{Co}$ dex Sangalensis 292 (9th century) and in the iconographic depictions of the pericope in the Latin Egbert Code (1oth century). ${ }^{12}$

\footnotetext{
${ }^{10}$ For more on this comparison, see: Schwarz 1982, 239-256.

${ }^{11}$ In this context, as Theobald emphasizes, Jesus' words that point to the sinfulness of "everyone" (including Christian listeners of the pericope) sound extremely elusive, to everyone except Jesus himself (Theobald 2009, 558).

12 This inscription has been used many times in the artistic representations of our pericope. An example is a wall painting from the 11th century in the church of San Angelo in Formis (Italy). The words terra terram accusat can also be a paraphrase of the words from the homily of Augustine in Ps 2:10 (Serm. 13: 4-6); where the bishop of Hippo reminded the groundly rulers that "the ground itself judges the ground." As ordinary mortals, Augustine reminded, rulers will also be tried. For more details see: Ronig 1977, 76.
} 
In another letter (Epistle 68.13), Ambrose claims that Jesus could have written his words that we know from the Gospel of Matthew: "And why beholdest thou the mote that is in thy brother's eye, but considerest not the beam that is in thine own eye?" $(7,3)$. According to Ambrose, Jesus wrote this twice because he wanted to refer to the two Testaments. Jews who accuse a woman of adultery will be charged in both the Old and New Testaments. In Epistle 68.14 Ambrose also says that Jesus wrote on the ground with the same finger with which he wrote the Old Testament law. In fact, the tables of the Decalogue are written with the finger of God himself (Ex. 31:18; Deut. 9:10). That is why Ambrose directly says that Jesus is the same God who gave the law to the people of Israel at Sinai. However, the Bishop of Milan does not suggest that the text written by Jesus is the Decalogue, although such a conclusion seems logical.

Starting from the assumption that both tables of the Law were written by God himself, and the inscription we are discussing is from Jesus himself, we see in the inscription an allusion to the law that God gave to Moses (Schöndorf 1996, 91-93; Burge 2000, 243). Some interpreters, beginning with Bede the Venerable in his homilies on the Gospel of John (1: 75-80), refer directly to the Decalogue as the text of Jesus' inscription (Guilding 1960, 112). The argument for identifying the inscription of Jesus as the Decalogue is the direct literary context in which the pericope adulterae occurs (Jn. 7-8), because many references to the Decalogue and the Law of Moses can be found in it. ${ }^{13}$ The temple as the place

\footnotetext{
${ }^{13}$ An allusion to the third commandment concerning the Sabbath observance (Ex. 20: 8-11; Deut. 5: 12-15) is found in Jn. 7: 21-23. The reference to the fourth commandment to honor one's father and mother appears in John

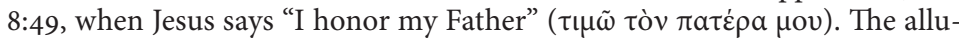
sion is noticeable on the lexical level because Jn. uses the same verb as Ex. 20:

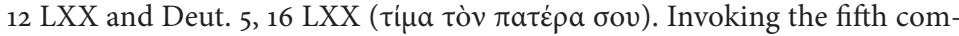
mandment of the Decalogue "Thou shalt not kill!" (Ex. 20: 13; Deut. 5: 17) we find in the words, "Did not Moses give you the law, and [yet] none of you doeth the law? Why seek ye to kill me?" (Jn. 7: 19). The allusion to the sixth commandment "Thou shalt not commit adultery" (Ex. 20: 14; Deut. 5: 18) is found in the very pericope we are analyzing, in which the woman is accused of
} 
where the scene described in the pericope takes place (8:2) is also reminiscent of the stone tablets of the Decalogue, because Jesus had to write on the stone floor of the temple courtyard.

According to J. A. Sanders, Jesus first wrote in abbreviated form the text of the first table of the Decalogue (Ex. 20: 3-12; Deut. 5: 7-16), and the second time he wrote an abbreviated text of the second table of the Decalogue, i.e. the remaining five commandments (Ex. 20: 13-17; Deut. 5: 17-21). The content of the second table, which contains references to one's neighbors, would force the writers to admit their sinfulness. ${ }^{14}$

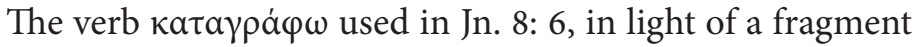
of a pyramid dating to 256 BC. (Zenon Papyrus 59), means persecution against someone. Based on that, R. A. Whitacre suggested that Jesus could have written the commandments of the Decalogue that women prosecutors had violated and thus formulated his accusation (Whitacre 1999, 207-208).

Ch. S. Keener also noted that writing the text of the entire Decalogue seems unlikely. While the woman's accusers called for the commandment "Thou shalt not commit adultery" (Ex. 20: 14; Deut. 5: 18), Jesus could write the commandment "Thou shalt not covet thy neighbor's wife" (Ex. 20: 17; Deut. 5: 21), which could apply to any of the plaintiffs. Ch. S. Keener notes that in the LXX the commandment that forbids lust begins with a neighbor's wife, while in the Hebrew text it speaks of a neighbor's house. As a result, Jesus presented a commandment to the prosecutors, against which they must have rebelled. Moreover, in Jesus' interpretation, the desire for a woman is equal to adul-

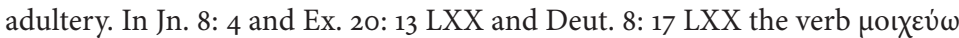
is used. The reference to the eighth commandment (prohibition of false testi-

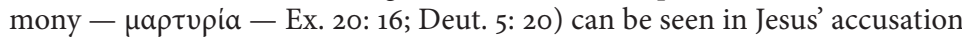
that his testimony is not true (Jn 8: 13) and in Jesus' response to this accusation that it is true ("Even if I bear witness of myself, my witness is true; for I know whence I came, and whither I go; but ye know not whence I come, or whither I go" (8: 14). See: Brooke 1988, 102-112.

14 The fact is that in the old days, the text of the Decalogue was usually shortened. Unfortunately, we do not know exactly where this custom came from and, therefore, whether it was practiced in the time of Jesus. More in: Sanders 1990, 342. 
tery (see Mt. 5:28). Jesus, therefore, determined the commandment by which he forbade lust on the same level as the commandment which the woman violated. He therefore presented to the prosecutors in writing a choice which also said, "He that is without sin among you, let him first cast a stone at her." (Jn. 8: 7). Accordingly, prosecutors realized that they were as sinful as the accused woman. Ch. S. Keener evaluates the above explanation as pure speculation and points to this weakness, which is the narrator's failure to indicate the content of Jesus' inscription. In the above interpretation, it is not the act of writing itself, but the content of the inscription that is the key to understand the dramaturgy of the situation. This reasoning is supported by the ancient rhetorical practice according to which the accused tried to show the involvement of prosecutors in the crime. If they could prove it, then they could force prosecutors to drop the charge. In the case of our pericope, Jesus would be the prosecutor of the prosecutors (Keener 2003, 737-738). ${ }^{15}$ On the other hand, Jesus did not have to write the above sentences to accuse the accusers, because the mere utterance of the phrase "He that is without sin among you, let him first cast a stone at her" (Jn 8: 7) was enough to reverse the roles. ${ }^{16}$

J. D. M. Derrett suggested that Jesus wrote the words of Ex. 23: 1: "Thou shalt not take up a false report: put not thy hand with the wicked to be an unrighteous witness." On the other hand, if in Jn. 8: 8, Jesus wrote the words of Exodus 23: 7a: "Avoid false words," Jesus would write only the first words of these verses, because the small number of letters is enough to write them, which did not require him to rise and move to suggest that the woman was the victim of her husband's plot,

\footnotetext{
${ }^{15}$ Keener also cites the works of ancient authors confirming the practice of prosecuting prosecutors during trials (Keener 2003, 753).

${ }^{16}$ Researchers who see Jesus' answer in the key of the ancient principle of part and shame as key values that determine the position of a person at that time are also noticeable. Prosecutors set a trap to deprive Jesus of his honor. Jesus, for his part, defends his honor by examining the status of prosecutors as honorable people. See: Raspberry 1998, 293.
} 
who called false witnesses to fabricate accusations against her (Derrett 1963, 18-23). As a counterweight to this interpretation, it should be noted that John's text speaks directly of a woman caught in adultery, and therefore there can be no false accusations. Accordingly to the regulations of the Torah, a woman is subjected to a just punishment. Moreover, Jesus does not question the sinful status of women (see 8:11). Acceptance of the above interpretation also requires an extremely creative reader of the Fourth Gospel, who adds more to the text than the text itself says or even suggests (Schnackenburg 1990, 165). Another disadvantage of this explanation is the fact that J. D. M. Derrett based his interpretation on his subjective calculations of the number of letters that Jesus could write in a sitting position.

R. D. Aus pointed to Mal. 2: 11 ("Judah hath dealt treacherously, and an abomination is committed in Israel and in Jerusalem; for Judah hath profaned the holiness of Jehovah which he loveth, and hath married the daughter of a foreign god.") as the first text in Jn. 8: 6 and Os. 4: 14 ("I will not punish your daughters when they play the harlot, nor your brides when they commit adultery; for [the men] themselves go apart with harlots, and they sacrifice with the prostitutes; and the people that doth not understand shall be overthrown.") as another written text in Jn. 8: 8 (Aus 1998, 28-34). This proposal, although extremely interesting, was not widely accepted in biblical scholarship. The ideas that should be seen in Jesus' text regarding Dn. 13: 5 should be seen as incredible ("Injustice arose among the judges - the elders of Babylon who considered them only leaders of the nation") ${ }^{17}$ by the habit of drink-

\footnotetext{
${ }^{17}$ From a historical point of view, this proposal is not convincing, because the text of Dn. 13 was known only in Greek (Jovanović 2018, 25), so it is difficult to assume that Jesus would have written this sentence in that language. The connection of the pericope adulterae with the story of Susanna (Dn. 13) is conditioned by the connection of these two texts in the Roman Liturgy from the fifth century. For a convincing critique of the search for a connection between Dn. 13 and our pericope, see Keith 2009b, 389-393.
} 
ing the bitter water of Nb. 5:16-24 (Burgon 1896, 239-240) ${ }^{18}$ or to the text of the Book of Esther (Bowman 1975, 177). ${ }^{19}$

Medieval art already saw in Jesus' words the words spoken in Jn. 8: 7 ("He that is without sin among you, let him first cast a stone at her."). Thus, on the golden cover of the 9th-century Latin Gospel in Trier (Codex Aureus Monacensis) we find a depiction of Jesus writing the words si quis sine peccato (Werchmestier 1963, 55). It is worth mentioning that Jesus' sentence had a double meaning: it was a condemnation (for the woman and the prosecutors), but also a mercy because it freed the woman. ${ }^{20} \mathrm{~K}$. E. Bailey thinks that Jesus first wrote the woman's death sentence (8: 6). However, Jesus' proposed execution (8: 7) meant that no one was able to do so because every Israelite felt sinful (Is. 53: 6). The topic of transcription (8: 8) was completely different. By writing and relying on the ground, Jesus wanted to avoid the public humiliation of his opponents, who leave the oldest to the youngest (Bailey 2008, 235). According to F. Godet and T. B. Manson, the scene described in the pericope, refers to a Roman judicial custom in which the president of the court first had to write (in a table) a verdict and then read it aloud. ${ }^{21}$ According to Manson, Jesus first wrote in

18 The custom described in Nb. 5: 11-31 applied to women accused of secret adultery. The accused woman had to drink bitter water, which extracted her curse of infertility if she was guilty or did not harm her if she was innocent. Burgon discusses the content of Jesus' inscription, claiming that a bitter punishment followed for the adulterers, but also speculating that the only connection between Jn. 8 and Nb. 5 is ground dust.

${ }^{19}$ In his monograph, the author tried to show the relationship between the Book of Esther and the Gospel of John. Accordingly, Jesus wrote Esther's name in Jn 8: 6 and the name Haman in Jn 8: 8, so the prosecutors in the accused woman were instructed to see the innocent Esther and the bloodthirsty Haman in her.

${ }^{20}$ Peter the Chrysologist, in his sermon on Rome 7 (Sermon 115.3), said quite generally that Jesus wrote the sentence of forgiveness in the sand, as opposed to the expected condemnation in relation to the body: condemned the body.

${ }^{21}$ F. Godet $(1879,310-311)$ argues that Jesus, in writing, alluded to the judicial office, which was attributed to him by his enemies at the time. Because the legal punishment is not only pronounced, but written. See also Jeremias 1951, 145-150. 
8: 6 what he later said to the Scribes and Pharisees in 8: 7, and then in verses 8: 8 what he said to the woman in verses 8: 11 . F. Godet and others suggest that Jesus wrote only the words in verses 8: 7 (Bruce 1983, 415; Morrice 1997, 35-36). Roman authorities had the right to issue the death penalty (ius gladii) at the time of Jesus.22 Jesus' gestures would therefore be a conscious allusion to Roman judicial practices that point to Jesus' right to make such a judgment (see Jn. 19: 11). The way Jesus judged ("He that is without sin among you, let him first cast a stone at her") means that no one is able to do it. Once again, the truth is confirmed that only God has the right to judge (Jn 8: 15-16). Ch. S. Keener noted that the historical context of the events speaks in favor of this solution. R. E. Brown denied the above proposal, noting that Scribes and Pharisees (and therefore female prosecutors) could read. It therefore seems strange that, after reading Jesus' sentence, "He that is without sin among you, let him first cast a stone at her" they continue to ask Jesus questions, seeking a reaction and taking a stand

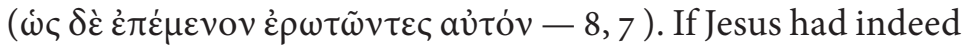
written this sentence, it would have been read and the prosecutors would have begun to abandon it, just as he did after Jesus uttered this sentence (Brown 1995, 334). R. Schnackenburg criticizes Manson's proposal, arguing that the starting point of all reasons should be Jewish, not Roman customs (Schnackenburg 1990, 165). However, it is difficult to agree with this accusation, given the widespread knowledge of Palestinian Jews about Roman practices regarding ius gladia, as evidenced by the Gospel of John itself (18: 31$)$.

The Serbian theological public is familiar with the interpretation of the pericope adulterae of St. Nicholai of Ohrid and Žiča in the sermon What did Christ write in the dust? (Velimirovich

\footnotetext{
${ }^{22}$ It is worth emphasizing, however, that adultery was not punishable by death under Roman law. If Jesus supported the use of the death penalty by stoning, he would be exposed to the Roman authorities. On the other hand, there were "spontaneous" executions by stoning, without reference to the authority of the Roman authorities, as shown by Stephen's martyrdom (Acts 7: 54-60).
} 
$2016,341-350) .{ }^{23}$ He judges the very scene of the dialogue between Jesus and the sinful woman by a "deliberate hellish plan to catch the Lord in a word contrary to the law, and to blame Him" (Velimirovich 2016, 346) about the content of the inscription, due to its unpleasant content. ${ }^{24}$ As the orator reports, the accelerated dramaturgy of the scene shown in Jn. 8: 9, which describes the departure of the Scribes and Pharisees, testifies to this: and Jesus was left alone, and the woman standing in the midst. Explaining the depth of shame that the Scribes and Pharisees experienced in this discussion, Bishop Nicholai refers to the folk tradition embodied in the belief that Jesus wrote the sins of his interlocutors on the ground. ${ }^{25}$ From the exegetical point of view, Nicholai's view of sins that Jesus wrote is especially interesting, as well as the explanation of the very act of writing that he gives below:

"But in vain to hide something from the eyes of the One who sees everything, and whose knowledge is seeing. M(eschulam) plundered the treasure of the church - he wrote the finger of the Lord on the dust; A(sher) committed adultery with his brother's wife; $\check{S}($ alum) swore wrongly; E(led) hit his parent; $\mathrm{A}$ (mariach) seized the widow's estate; $\mathrm{M}$ (erari) committed the sin of Sodom; J(oel) worshiped idols. And so in turn he wrote on the dust the terrible finger of a righteous Judge. And

\footnotetext{
23 The first integral version of this sermon was published in 1931 in the brochure of the same name in the edition "Pobožne knjige za narod", by the Belgrade publishing house "Đura Jakšić. In the meantime, it has been published in several different editions, and on this occasion we use the eighth book of the Collected Works of Bishop Nicholai.

24 "It's too disgusting and disgusting to write in the Book of Joy." (Velimirovich 2016, 347).

25 "He wrote something unexpected and devastating for those elders, the prosecutors of the sinful woman. He pointed out their most hidden iniquities with his finger on the dust. Because these hunters of other people's sins and judges of public sinners and summoned sinners were experts in hiding their sins." (Velimirovich 2016, 347).
} 
those concerned were bent over reading what was written with unspeakable horror. Behold, their most skilful hidden week, which trampled on the law of Moses, was known to Him and is now written before their eyes. At one point, their mouths went silent. The arrogant boasters of their justice and even more arrogant judges of other people's injustice now stood silent and motionless like rocks in the walls of the temple. They trembled with fear. They were not allowed to look each other in the eyes. They didn't even think about the sinful woman anymore. They thought only of themselves and of their death, which was written in the dust. No language could move to say that boring and cunning question: what do you say? The Lord says nothing. He said nothing. He was disgusted to confess their sins with His pure mouth. That is why he resorted to writing in the dust. What is so dirty only deserves to be written on dirty dust. The second reason why the Lord wrote in the dust is even greater and more miraculous. What is written in the dust is quickly erased, and does not remain. And Christ did not want to reveal their sins to everyone." (Velimirovich 2016, 347-348)

This part of Nicholai's sermon remains especially enigmatic for us. Completely different from all other, both ancient and modern comments, the bishop announces not only the names of Jesus' interlocutors but also the sins they bore and which Jesus wrote down on the ground to shame them. However, it is impossible not to wonder where Bishop Nicholai draws the source for such a claim from, especially having in mind that this interpretation, to our knowledge, is unique in the entire tradition of interpreting the fourth Gospel. Also, it is obvious that Nicholai does not speak about the Old Testament persons, because the inscription refers to each of them individually and therefore states that "they were not allowed to look each other in the eye" (Velimirovich 2016, 348). Since we do not have clear evidence, we can assume that Bishop Nicholai probably found the material for the sermon in the 
work of Pavel Matveyevsky Evangelical History, which he met during his stay in Russia. Matveyevsky is the only known author whose interpretation of this scene somewhat coincides with Nicholai's, ${ }^{26}$ although he himself states that it is an ancient interpretation (Matveyevsky 1890, 532). Leaving room at this point for some further research, focusing on the sources of Nicholas' sermons, ${ }^{27}$ we can still state that, although completely absent in other preserved comments of the pericope adulterae, this section served our speaker as an hermeneutic key to understanding the depth of sins such as perjury, idolatry and others. ${ }^{28}$

26 "According to the ancient interpretation, the Pharisees and Scribes, preoccupied with curiosity, came to him to find out what he was writing. And now, when one of them came very close and began to look over his shoulder, he suddenly saw that Christ, even without looking at him, wrote down his name and the sin he had once committed: 'Asher — he seduced his brother's wife.' Oh my God! it's a secret, no one saw them! How does he know ?! Fearing that his iniquity would be exposed and he would be stoned, the Pharisee left quickly. Another Pharisee, interested in why this Asher left so quickly, also appeared behind Jesus Christ. His sin is also indicated: 'Meshullam stole the church treasury.' The Pharisee was terrified: 'No one knows about this, and now the trial continues, they are looking for a thief, and Jesus can tell about me. Then they will find the money and stone me.' And recognizing the great prophet in Jesus, he also hurried to leave. A third also approached. Jesus Christ, not turning back, but knowing who was behind him, wrote, 'Jonathan, caught in the hands of robbers, blasphemed the God of Israel and denied him.' The frightened Pharisee ran out of the temple. One by one, beginning with the elders (Jn 8: 9), they approached him and read: 'Shallum swore falsely ... Eled struck his father"' (Matveyevsky 1890, 532).

${ }^{27}$ It should also be noted that Bishop Nicholai and Pavel Matveyevsky do not completely agree in stating the names of the Pharisees and their sins that Jesus was supposed to write on ground. While Nicholai speaks of seven names (Meshullam, Asher, Shallum, Eled, Amariah, Merari, and Joel), Matveyevsky's interpretation boils down to five of them (Asher, Meshullam, Jonathan, Shallum, and Eled). Despite everything, the question of the source for Nicholai's claim about Amariah and Merari remains.

${ }^{28}$ It is also interesting that the seven names from Nicholai's sermon are repeated by Milivoje Jovanović in the novel Monk Callist from 1984, which has also experienced several newer editions in recent years, so it is understandable that this story came to life deeper in the readership. 


\section{Discussion about the reasons for writing}

Since the content of the inscription made by Jesus does not mention the narrator of the pericope, it is often concluded in the New Testament scholarship that he was not important (Brwon 1994, 334). The significance of Jesus' work lies, therefore, not so much in the content of the inscription as in the activity itself, i.e. in the very fact of writing. ${ }^{29}$ However, it is worth emphasizing that this should not be concluded from the fact that the text of the inscription is not familiar with the insignificant importance of writing. Interpretations appear that deny the validity not only of the inscription (which we do not know), but also of the act of writing. ${ }^{30}$ Dual information about Jesus' act of writing clearly places emphasis on this activity, and therefore Jesus' behavior must express something significant (Schnackenburg 1990, 166; Burge 2000, 242).

In the minds of the ancients, writing on ground, sand or dust was a behavior that by its nature did not communicate a certain content. This behavior expressed the subject's address to himself. This act, which did not focus on the transmission of certain content, was in fact a sign indicating a lack of availability for interpersonal communication (Hengstenberg 1865, 423). If the above belief of the ancients were applied to John's text, Jesus' action would mean aversion to any dialogue with the Scribes and Pharisees surrounding him. This interpretation

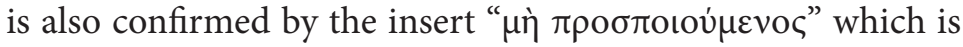
found in many manuscripts at the end of Jn $8: 6 .^{31}$

\footnotetext{
${ }^{29}$ According to O'Day, the story does not provide any information about the content of what Jesus writes, because the very act of writing is important. Interpretations that attempt to convey the content of what Jesus writes miss the significance of Jesus 'nonverbal response (O'Day 1996, 629).

${ }^{30}$ Proof of the lack of understanding of the function of this gesture in the pericope is the ancient paraphrase written in Syriac in Historia Ecclesiastica 8.7 (6th century), a work wrongly attributed to Zacharias Rhetor. This text puts Jesus 'gesture of writing at the very end of the event, while Jesus and the woman were alone (Strachan 1941, 204; Knust 2006, 523).

31 This part first appears in the Codex Basiliensis from the 8th century, and the following witnesses are three codices from the 9th century: Codex Seidelianus I
} 
In light of the above belief, J. H. Bernard stated that Jesus only unconsciously wrote with his finger on the ground. It was a mechanical act that meant an unwillingness to comment on a question posed by Scribes and Pharisees and expressed concern for their own thoughts (Bernard 1928, 719). B. F. Westcott notes that any search for the contents of the record does not make sense, because the message of the text is limited only to the display of "mechanical writing". Jesus' actions show that he is focused on his own thoughts and neglects the presence of people who ask him (Westcott 1882, 126). According to Hoskyns, Jesus' gesture means only an unwillingness to judge in the presence of prosecutors (Hoskyns 1947, 569). Similarly, B. Lindars sees the act of Jesus as a sign of his unwillingness to participate in the whole event, as shown in verses 8, 7 (Lindars 1972, 310-11). Ch. K. Barrett commented in the same vein, saying that there was no point in asking about the content of the inscription, because by writing, Jesus demonstrated in a sophisticated way the refusal to issue a sentence in the spirit of the later statement in Jn. 8:15 "I judge no man" (Barrett 1978, 572). ${ }^{32}$ The proposal made by A. T. Lincoln goes in the same direction, who sees the withdrawal gesture in writing. Jesus avoids directly facing the challenge proposed by the prosecutors, leaving them to wait impatiently. ${ }^{33} \mathrm{~J}$. M. Lagrange, in an interpretation that has received a lot of criticism, believes that by writing on the ground, Jesus expresses an attitude of inactivity (cf. Aristophanes, Acharn. 31) or, focusing on the act of writing, concentrates on his own thoughts (Lagrange 1936, 229).

and II as well as Codex Ciprius. The remaining manuscripts date from the following centuries, and the largest number of witnesses (twelve) dates from the 12th century. Read more in: Robinson 2005.

32 See also: Dietzfelbinger 20042, 233.

${ }^{33}$ According to Lincoln, this has the consequence of distracting him from the immediate challenge and diverting attention from opponents, who are temporarily caught in an unfavorable position, because then they have to persistently ask their question (Lincoln 2005, 531). Maloni goes further and sees this as a sign of indifference and even disappointment with the procedure (Moloney 1998, 261). 
F. D. Bruner understands Jesus' gesture of writing as a way to divert the accuser's attention from the woman. In this way, according to him, Jesus also adds drama to the whole situation. He gives himself time to think before he answers, which proves the truth of his human nature. However, Jesus' second gesture of writing reflects something quite different: he is willing to distract the crowd from the accused prosecutors. Jesus protects the accused in this way (Bruner 2012, 505-506). According to O'Day, Jesus' gesture of writing associated with a lack of immediate and direct response deprives Scribes and Pharisees of control of the situation and puts them on the same level as the accused woman (O’Day 1992, 636-637). J. R. Seeley in his unique and often criticized view of this pericope, believes that Jesus is ashamed. He could not look at the crowd around him, the prosecutors and the woman. Embarrassed and confused, Jesus lowers his head to hide his face and begins to write. ${ }^{34}$ Among many other interpretations, in De cons. ev. 4,10,17 Augustine also gave one in which the bending of Jesus' head and the placing of signs on the ground are an expression of his humiliation. In his commentary on the Gospel of John, however, Augustine stated that Jesus, striking the accusers with the word of justice ( $8: 7$ ), did not want to see their public humiliation and began to write again..$^{35}$ Another ancient author, Cassiodorus the Senator, saw in Jesus' gesture a reaction to the hardness of the accusers (Exp. Ps. 56: 7).

Also, there was a suggestion that the evangelist introduced the act of writing around the ground into the text as an addi-

\footnotetext{
${ }^{34}$ Seeley speaks of Jesus' unbearable sense of shame. He claims that Jesus could not meet the eyes of the crowd or the accusers, and perhaps at that moment not even from the woman, but in his ardent shame and confusion, he bent down to hide his face, and began to write with his finger on the ground. (Seeley 1866, 116).

${ }^{35}$ Augustine, In ev. Ioh. 33,5,33. In a similar vein, Jerome (Pelag. 2: 17, 23-29) described how the prosecutors left the courtroom to avoid the eyes of Jesus, who, as a merciful judge, bent down, giving them the opportunity to leave in their shame: "and because all the prosecutors fled (namely, the merciful judge had given their embarrassment room to retreat, returning his gaze to the ground as he wrote on the ground), parted a little, and began to avoid his gaze."
} 
tional interpolation, disturbing the natural dynamics of the story. It functions as a pause, postponement or cessation of dialogue aimed at increasing tension and at the same time showing the peace of Jesus (Becker 1963, 85-87). Becker considers the writing of Jesus to be a literary ornament (novellistich-ausschmückendes Detail) irrelevant to the development of the narrative. At best, this gesture describes waiting for Jesus, who ceases to be interested in his opponents and leaves them to themselves (Becker 1979, 284). Some commentators interpret the break in a positive way. According to A. Watson, Jesus refrains from the sentence and, having begun to write, wants to postpone his answer. In this way, however, it gives interlocutors time to think (Watson 1980, 103). In the same vein, L. A. Guardiola-Saenz sees Jesus' gesture as a "space of silence" to help prosecutors reflect and revise their oppressive patriarchal stance (Guardiola-Sáenz 2002, 148). Similarly, B. H. Young considers the act of Jesus a prophetic gesture aimed at attracting the attention of accusers and making them think (Young 1995, 69).

P. Humbert believes that Jesus' gesture has magic and magical properties, so Jesus creates a magical act by pulling his fingers on the ground, so that the lines created by this gesture take the form of letters to finally utter the spell (Humbert 1918-19; 475-476). E. Power, referring to Arabic texts, believes that Jesus is expressing his anger. In fact, this action expresses the irritation of Jesus who sees the hypocrisy of the Scribes and Pharisees. In this way Jesus also reveals his compassion for women (Power 1921, 54-57). A. J. Wensinck and after him F. F. Bishop, also mentioning the Muslim tradition, saw in Jesus' gesture a sign of reflection on an issue that requires serious thinking. ${ }^{36}$

Based on the above interpretations, it is worth noting that a proposition that sees the unconscious creation of characters (e.g. drawing) in the works of Jesus, rather than consciously

\footnotetext{
36 Wensinck $(1933,302)$ argues that it will be clear that Jesus does not write in the field as an indication of overlooking the questions of his opponents or his disrespect for them, but on the contrary, because he thinks of a difficult case and a serious answer that shapes in his mind. See also: Bishop 1934, 45.
} 
writing a particular text or letter, has its support in the seman-

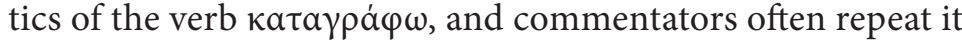
(Keddie 2001, 314; Neyrey 2007, 152). However, the total value

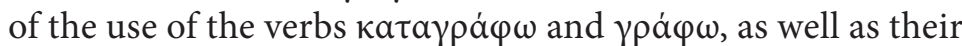
meaning in the LXX and New Testament, accurately indicates the act of writing and is in contradiction with the above interpretation (Keith 2009b, 27-49).

It is also suggested that the material he wrote on, and thus the ground or dust of the ground, is an important element in which he can correctly interpret Jesus' activity. In the Jewish tradition, it is forbidden to write on the Sabbath, or even to write two letters. The Talmud, however, says that writing on the Sabbath on the ground, in the dust of the ground, or on other unstable material is not wrong and cannot be punished. In the current literary context of the Gospel of John, the scene takes place on the seventh or eighth day of the Feast of Tabernacles (7:37), which is respected as a Sabbath day. Therefore K. E. Bailey believes that by writing on the ground, Jesus shows his perfect knowledge not only of the written Law (Torah), but also of its oral interpretations (Bailey 2008, 234).

On the other hand, writing material on the ground can suppress immutability (Bernard 1928, 719). Jesus would thus point to the permanence, weakness, nothingness, and transience of those who accused (Strack 1924, 521). Writing on the ground is the opposite of writing in the Book of Life (Ex. 32:32; Dn. 12: 1). Whoever rejects God, the source of the water of life (Jer. 17:13) or Jesus, the true source of the water of life (Jn. 7: 37-38), condemns himself to death, that is, by writing in the dust of the ground Jer. 17:13 (Whitacre 1999, 207). A gesture of writing on the ground would thus indicate the fate of a sinner to die or go to Sheol. It is worth noting, however, that the permanence of writing the material also illustrates the permanence of sin before God's forgiveness and the greatness of God's mercy that forgives human sin. As H. Ridderbos suggests that Jesus, writing on the ground, wants to point out the existence of situations in which, instead of sticking to the let- 
ter of the law, it is better to "write on the sand", to forgive, to reject punishment (Ridderbos 1997, 289).

Augustine also claimed that writing on the ground could be a symbol of the coming time when the Law / Decalogue (correctly interpreted by Jesus) would be written on fertile ground, as opposed to the time when the Law was written on stone, and therefore on barren land. ${ }^{37}$ In modern times P. S. Minear read the gesture of writing on the ground as undoing the curse of the ground, mentioned in Gen. 4: 10-12 (Minear 1991, 29). It is not without significance that the Temple in Jerusalem, where the action of the pericope takes place, was in the Jewish tradition connected with Eden, the cemetery of Adam and Eve. Interestingly, Augustine compared Jesus' gesture to God's gesture, which bent over man when it was said: "For dust thou art, and unto dust shalt thou return" (cf. Gen 3:19)..$^{38}$

The gesture of writing on the ground and at the same time Jesus' attitude was also read metaphorically as expressing the humility of Jesus who accepts human nature. Jesus' writing gesture is also explained by starting from the detail, which is the finger, and reading it in the context of the Old Testament texts about the "finger of God" (Brodie 1993, 158-159). Assuming that the recipients were primarily Judeo-Christians, i.e. people familiar with the Old Testament and recognizing the deity of Jesus, such an intertextual reference is possible. However, remaining on a historical basis (the text would correspond to the historical reality of Jesus' encounter with the Scribes and Pharisees), this understanding seems difficult to accept, because Jesus' opponents certainly did not see him as God writing with a human finger on the ground as he did in the Ex., writing the Decalogue

\footnotetext{
${ }^{37}$ Augustine, In ev. Ioh. 33.5.15-18: "What else could he have pointed out to you while he was writing on the ground with his finger? Namely, the Law of Moses was written with the finger of God, but because of the hardened (with the heart) it was written on stone. Now the Lord wrote on the ground because he was looking for fruit." More in: Beutler 2013, 265; Kelber 1997, 18.

38 Augustine, Enarrat. Ps. 2,30,7: "He was bowed to the ground again, that is. God bent down to the man who was told, 'You are the ground and you will go to the ground"."
} 
(Ex. 31:18; 32:16; Deut. 9:10) or in the time of the prophet Daniel, writing on the wall (Dn. 5:25).

Many commentators point to the main theological purpose of mentioning the writer Jesus, portraying Jesus as the new legislator, and as God, the author of the Decalogue (Coleman 1970, 409-410; Genuyt 1986, 21-32). The very context of the trial in which the writer Jesus is mentioned remembers Moses and the time of the Exodus. Like God, in the days of his exodus he was questioned by the rebellious people of Israel (verb $\pi \varepsilon \iota \rho \dot{\zeta} \zeta \omega-$ Ex. 17: 2.7; Nb. 14: 22; Ps. 77: 41.56 LXX), similarly to God, in the person of his Son, another attempt was made ( $\pi \varepsilon \iota \rho a ́ \zeta \omega$ in Jn. 8: 6).$^{39}$ Jesus' interlocutors directly remember Moses and compare Jesus to him: "Now in the law Moses commanded us to stone such: what then sayest thou of her?" (8: 5). In response, Jesus begins to write, which the author of the pericope in turn describes with

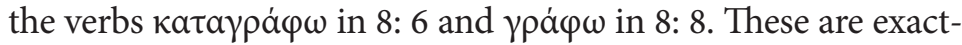
ly the same verbs used in the description of the two tables of the Decalogue in Ex. 32: 15 LXX. Moreover, they appear in both texts (Exodus and John) in the same order. Furthermore, according to Ex. 31:18 LXX (see also Ex. 9:10 LXX), these tables are written with God's "finger". I would add that Jesus also writes with

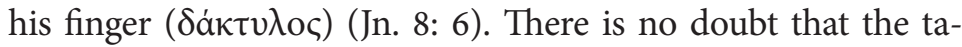
bles of the Decalogue were written by God himself, for Ex. 32:16

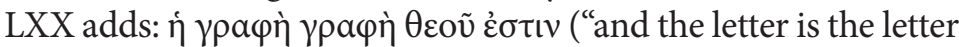
of God"). Therefore, the Pericopean narrative suggests that Jesus is not only greater than Moses, but more importantly that he is equal to God, the author of the Decalogue. The fact that the act of writing in the Ex. takes place on stone tablets, and in John's narration on the ground, is not important here.

\footnotetext{
${ }^{39}$ Extremely eloquent in John's context (which defines the identity of Jesus as God and the new Moses) is the song Ex. 17: 2, where he quarrels with Moses and

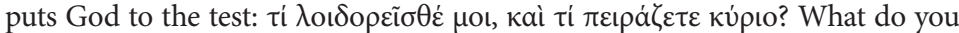
tempt the Lord?). Just as in the Pentateuch, God is the one who puts his people to the test (Ex. 15: 25; 16: 4; 20:20; Deut. $4: 34 ; 13: 4)$ and puts himself to the test, so in the Gospel according to John Jesus stands on the test of Philip (6: 6; the context of manna and Exodus) and is put to the test itself.
} 
L. Manicardi, at the suggestion of F. Genuyt, suggests that the double bending and ascent of Jesus is interpreted as an allusion to the double entry and descent of Moses from Mount Sinai at the time he received the tables of the Decalogue (Genuyt $1986,156)$. Since the first tables were destroyed because of a human sin, it was necessary to put together others (see Ex. 32-34). The gift of the other tablets actually refers to the gift of God's forgiveness, which corresponds to the message of John's text in which Jesus, after his Resurrection, utters the words of forgiveness. Before other tables are prepared, God reveals his name "forgiving iniquity, unbelief, and sin" (Ex. 34: 5-7). Indeed, in John's text, both the accusers (8: 7) and the woman herself (8: 11) are described as sinners who break the law and therefore need forgiveness. Jesus, however, throughout the Gospel

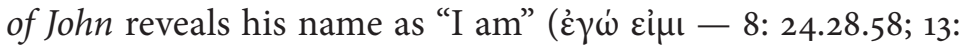
19; 18: 5.6.8), an echo of God's name revealed in Ex. 3: 14 (I am that I am - $\dot{\varepsilon} \gamma \dot{\omega} \varepsilon \dot{\imath} \mu \mathrm{o} \dot{\omega} v)$, which in turn is explained in Ex. 34: 6-7. L. Manicardi also emphasizes another possible parallel between Moses and Jesus. Well, Moses, innocent, gathered himself among sinful people in his prayer to God ("and pardon our iniquity and our sin, and take us for thine inheritance." - Ex. 34: 9). Similarly, Jesus, innocent and without sin (Jn. 8: 46), was condemned to stoning (8: 59), accepting some kind of punishment (8:11) for a sin he did not impose (Genuyt 1986, 156). In short, the double act written by Jesus would be a reference to the double editing of the Decalogue. ${ }^{40}$

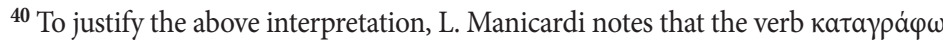
was used to describe the first tables (Ex. 32: 15 LXX), while the verb $\gamma \rho \alpha \dot{\varphi} \varphi \omega$ (Ex. 34: 1.27.28 LXX) appears in the description of the other tables. As we mentioned above, the same two verbs in John's narrative appear in the same order, describing the first and second acts of writing in turn. The fact is, however, that in the descrip-

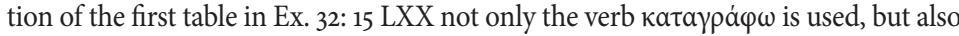
$\gamma \rho \alpha \dot{\alpha} \omega$. This somewhat undermines the legitimacy of the author's arguments. Manicard also refers to the use of verbs that express the movement of "ascending" and

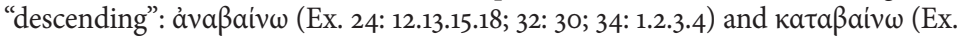
32: 1.7.15; 34: 29). However, in the description of Jesus' activities we notice the use

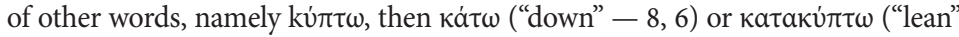


L. Manicardi also emphasizes the novelty of Jesus' behavior in relation to the parallel we find in Moses' work in Ex. 3234. While Moses first ascends and then descends, Jesus does the opposite: first he descends (bends), and then he ascends

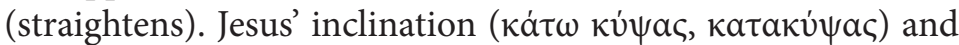

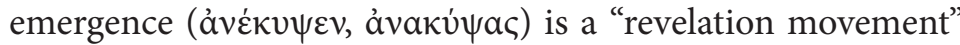

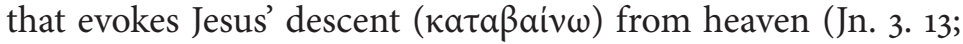
6: 33.38.41.42.50.51.58). Therefore, the changes in Jesus' attitude have Christological significance: they reveal Jesus' humility (kenosis) and at the same time His exaltation, because the Cross in the fourth Gospel is the glorious moment of Jesus' exaltation (Manicardi 2001, 159-160). The reference to the Mount of Olives is also significant in the context of such an interpretation (8: 1) (related to the arrest and consequent death of Jesus, see 18: 1) and the narrator shows the real intentions of the Scribes and Pharisees who wanted to accuse Jesus (8: 6).

F. Genuit and L. Manicardi point out another parallel between Jesus and Moses, which clearly emphasizes the novelty of the gospel message. Thus the content of Jesus' inscription, which symbolizes the Decalogue, and more broadly, the Law, is updated with Jesus' saying or word. The comparison of Scripture with the words of Jesus corresponds to the conflict of the Law and the words of Moses present in the statement of the Scribes and Pharisees: "Now in the law Moses commanded us

- 8: 8) and ảvakú $\tau \tau \omega$ ("straighten up" - 8: 7.10). In addition to identical prefixes, it is therefore difficult to speak of a clear lexical connection between the text of the Book of Exodus and the Gospel of John. Manicardi also points to the similarity of

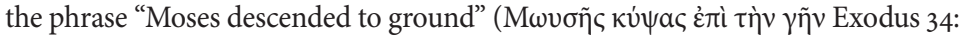
8 ), and John's statement "and Jesus stooped down, and wrote with his finger upon

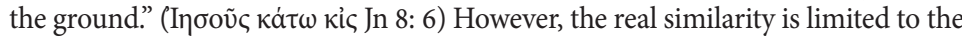
use of the same verb kú $\pi \tau \omega$.The second parallel pointed out by Manicardi is the use of the expression "all the people" ( $\pi \tilde{a} \varsigma$ ó $\lambda$ aò $\varsigma$ ), which also appears in Ex. 32: 3 LXX and Jn 8: 2. The use of this phrase is, however, too common in LXX (see Ex. 32: 10;34:10) to attribute special merit to the attribution of any special texts. Manicardi also suggests the hypothetical effect of the verb o $\rho \theta \rho i \varsigma \omega$ ("rising early in the morning") found in Ex. 32: 6 and 34: 4 LXX on the presence of the noun ö $\rho \theta \rho o c$ ("morning") in Jn 8: 2, which is the hapax legomenon in John's text. His speech is usually explained by Luke's influence (cf. Lk 24: 1; Acts 5: 21). 
to stone such: what then sayest thou of her?" (8: 5). However, the relationship between the Scripture (the Law) and the word of Jesus is different from the relationship between the Scripture (the Law) and the word of Moses. While in the case of Jesus the Scriptures are surpassed by the word that updates the Scriptures, in the case of Moses his words or commands correspond exactly to the commandments of the Scriptures (1:17; 5: 46-47).

In short, the content of Jesus' inscription may refer to the Decalogue or the Law. The double gesture of writing can refer to the double gift of the Decalogue / Law in Sinai. However, the narrator does not focus on the content of the record, but on the identity of Jesus as the real author and interpreter of the Law. Jesus is not only the new Moses (legislator and interpreter of the Law) and God himself, the author of the Law (actual and final legislator), but he is also the Word and the Law. ${ }^{41}$ In that sense, the record that Jesus left in John 8: 8 is illegible and it should be because it refers to Jesus' only true writing, which was Himself and his work. ${ }^{42}$

\footnotetext{
41 This interpretation is also confirmed by Jesus' identification with light, which occurs in the closest literary context (Jn. 8: 12). The law is interpreted in Judaism as light. The Hebrew text Is 26: 9 is "because when your judgments are on ground" they are given in LXX as "because when your judgments are light on

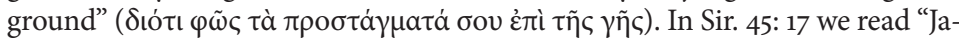

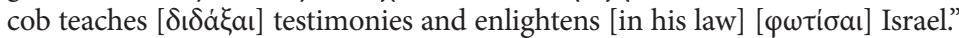
In 4Q175, in the quote from Deut. 33: 10 (Leviticus blessing), the words "They teach thy statutes to Jacob and thy law to Israel" were changed to "Let them declare thy commandments to Jacob, and your law to Israel." In Isaiah 2: 5 we read: "House of Jacob, let us walk in the light of the Lord", while in Targum we read: "Come, let us go and study the Torah of the Lord." In Isaiah 42: 7 we read: "Open the eyes of the blind", while in Targum we have: "Open the eyes of the House of Israel, who are blind without the Torah". In Jb. 24:13 we read, "They resist the light, not knowing its ways, and do not stand in its paths", while Targum explains, "They are among the rebels against the Torah". Other examples are: Gaster 1958, 217-218; Vermes 1958, 436-438.

${ }^{42}$ In this sense, the statement should be understood: "The Gospel of John finally shows the reader what Jesus wrote and that the words of Jesus (recorded in John 8: 6 and 8: 8) appear in the texts of Jn. 20: 30-31 and 21: 24-25. In other words, the written words of Jesus appear, not in John 8, but at the very end of the Gospel of John." (Aichele 2004, 364).
} 


\section{Did Jesus really write?}

\section{Pericope as an apologetic interpolation}

According to some commentators, the act of writing Jesus in the context of the event described in the pericope adulterae seems so strange that its uniqueness in itself becomes an argument for the authenticity of this act. In his doctoral dissertation he defended at the University of Edinburgh in 2008, Keith asserted that John's mention of Jesus' writing on ground was fabricated (8: 6.8), and that the pericope adulterae based on a real event in Jesus' life was an appendix to the original text of the Fourth Gospel. (Keith 2008, 433). The purpose of this apologetic act, according to Kate, would be twofold.

First, the pericope should refute the Pharisees' claim in the pages of John that Jesus was uneducated: "How knoweth this man letters ( $\gamma \rho \alpha \dot{\mu} \mu \alpha \tau \alpha)$ having never learned?" (7: 15). Moreover, if we refer to "this multitude that knoweth not the law" (o

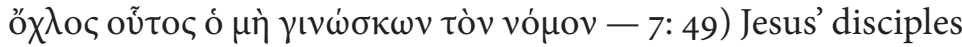
and followers, extrapolation can assume that Jesus is included in this group. Keith sees this as a general statement that defines the knowledge of the Law among the Galileans, among whom Jesus should be seen (Keith 2008, 433). Therefore, the purpose of the pericope adulterae was to prove that Jesus achieved the highest level of education at that time, i.e. that he was able not only to read, but also to write at a level equal to his interlocutors. Jesus can, therefore, be an equal partner for a conversation with the scribes (oi $\gamma \rho \alpha \mu \mu \alpha \tau \varepsilon \tilde{\varsigma}$ - Jn 8: 3), who represent the most educated social stratum of modern Palestinian Judaism. It is important that the scribes appear only here in the entire Gospel of John, which can be seen as a testimony to the interpolative nature of this pericope. Of course, the accusation of not accepting education in Jn. 7:15 does not necessarily mean the impossibility of reading and writing, but only the lack of formal studies of sacred texts in addition to a recognized rabbi or sage. A similar situation is described in Acts 4:13, where 


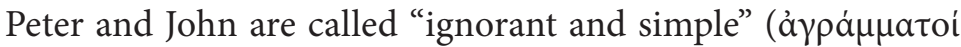

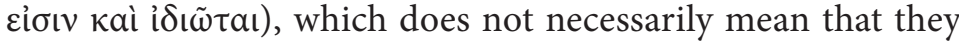
cannot read (Evans 2012, 81). It is also worth noting that the charge in Jn. 7: 15 is quite ironic. Jesus' interlocutors, believing Jews, face the eternal Word (creator of the world and personified divine wisdom) and say that this Word is an uneducated, unlearned person, without formal authority to be a teacher. Importantly, the author of the pericope describes Jesus' response in a way that is encouraged by Ex. 32-34, i.e. the portrayal of Jesus as the very giver and author of the Law, God, and thus in every possible way surpasses the authority of the scribes, including Moses himself.

According to Keith, the second purpose of the anonymous author who added the pericope adulterae in the 3 rd century was to answer the pagans (Celsus, Lucian of Samosata, Galen) that the first Christians and Jesus himself, the founder of Christianity, were uneducated and especially illiterate (Origen, Celsus. 1.62; Lucian, Peregr. 11; Minucius Felix, Oct. 5: 2-4; Justin, I Apol. 6o.) Allegations of illiteracy of the early Christians contradict figures such as Paul of Tarsus, his closest associates, or the evangelists themselves who belong a group of Jesus' closest disciples (Matthew, John) or first-generation Christians (Mark, Luke). Historically, the question of Jesus' literacy remains a moot point. ${ }^{43}$

In short, an important argument supporting Keith's hypothesis is the fact that the pericope adulterae is a subsequent interpolation to the original text of the Gospel of John. This hypothesis also provides an alternative to the generally accepted explanation that indicates the motive for its subsequent inclusion in the text. The weakness of Keith's hypothesis is the fact that no early Christian author cites the pericope adulterae as proof of Jesus' literacy. So, despite Kate's claim about the burning problem of Jesus' illiteracy as an accusation against Chris-

\footnotetext{
43 The problem of Jesus' literacy taken from a historical point of view is beyond the scope of this study. Some researchers claim that Jesus was literate, e.g. Foster 2006, 7-33; Evans 2012, 63-88. Other authors, however, argue that Jesus was not literate: Craffert 2005, 5-35; Keith 2011.
} 
tians, which, in his opinion, caused the growth and interpolation of the pericope adulterae, no Christian author used this text for the apologetic purpose for which it should have arisen. ${ }^{44}$

\section{Conclusion}

Purely hypothetical considerations regarding the content of Jesus' inscription focus on three propositions: a quote from the Old Testament (mostly Jer. 17:13), Jesus' judgment, and the words quoted in John 8: 7 ("He that is without sin among you"). In fact, the most convincing solution is an intertextual reference to the Decalogue. This is indicated by the context of the pericope (John 7-8), which contains many references to the Ten Commandments, as well as the theme of the story itself focused on the commandment "Thou shalt not commit adultery." In addition to the hypothetical content of Jesus' inscription, Jesus' act itself can be understood in several ways. For example, Jesus lowered his head in humiliation and shame or, on the contrary, Jesus lowers his head so that he would not know about the humiliation of his opponents who leave the stage. Undoubtedly, the double information about Jesus' gesture indicates the importance of this activity. The most convincing explanation for Jesus' act is the portrayal of Jesus as God, the author of the Decalogue. The text of the pericope reveals many connections with the narration of Ex. 32-34.

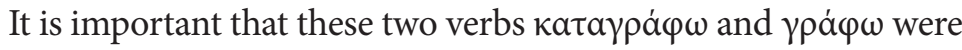

\footnotetext{
44 The fact is that this pericope may have been an "unwanted" text and therefore not included in the canonical Gospels because of its message that suggests a far-reaching forgiveness for the sin of adultery. This message was contrary to the practice of the early Church, in which adultery was the exclusive sin. The inclusion of the pericope in the canonical writings could coincide in time with the introduction of criminal practices and the verdict on the possibility of forgiveness of the sin of adultery. This could have happened around the year 220 in Rome. The location of the pericope in John, and not in another canonical gospel, may have its motif in Jesus' statement: "You judge by the flesh, I judge no one. But if I judge, my judgment is true, for I am not alone, but I and the Father who sent me" (8: 15-16). See: Riesenfeld 1952, 106-111.
} 
used in this order to describe the two tables of the Decalogue in Ex. 32, 15 LXX and the activities of Jesus. Both activities were performed with God's finger (see Deut. 9: 10) and on the same stone material (in the Gospel of John it is the foot of the temple). The repetition of Jesus' gesture can also be understood as a reference to the double ascent and descent of Moses from Mount Sinai, and thus to the double gift of the Decalogue. Among other details about the pericope that Jesus confronts with Moses, there is a clear tendency for the author of the narrative to show that Jesus' identity is superior to Moses. Jesus, therefore, appears as the new Moses (Lawgiver and interpreter of the Law), as God himself, the author of the Law (real and ultimate Lawgiver), but also as identical with the Word and the Law. Keith's proposal, which sees the pericope adulterae as an apologetic interpolation that points to Jesus' literacy, is plausible, although it has the status of a hypothesis.

$$
* * *
$$

\section{Bibliography}

Atherton, Mark. 200o. "A Place for Mercy. Some Allegorical Readings of 'The Woman Taken in Adultery' from the Early Middle Ages (with Particular Reference to Bede, the Heliand, and the Exter Book)." In Ciphers in the Sand: Interpretations of the Woman Taken in Adultery (John 7.53-8.11), Biblical Seminar 74, edited by Larry Joseph Kreitzer and Deborah Rooke, 105-138. Sheffield: Sheffield University Press.

Aus, Roger David. 1998. 'Caught in the Act', Walking on the Sea, and the Release of Barabbas Revisited, South Florida Studies in History of Judaism 157. Atlanta: Scholars Press.

Bailey, Kenneth E. 2008. Jesus Through Middle Eastern Eyes. Cultural Studies in the Gospels. Downers Grove: InterVarsity Press.

Barrett, Charles Kingsley. 19782. The Gospel according to St John. An Introduction with Commentary and Notes on the Greek Text. London: SPCK. Beasley-Murray, George R. 1999². John, Word Biblical Commentary 36. Waco: Word Books / Nashville: Thomas Nelson. 
Becker, Jürgen. 1979. Das Evangelium nach Johannes. Kapitel 1-10, Okumenischer Taschenbuchkommentar zum Neuen Testament 4.1 / Guitersloher Taschenbücher. Siebenstern 505. Gutersloh: Mohn / Würzburg: Echter.

Becker, Ulrich. 1963. Jesus und die Ehebrecherin. Untersuchungen zur Textund Uberlieferungsgeschichte von Joh. 7,53-8,11, Beihefte zur Zeitschrift für die neutestamentliche Wissenschaft und die Kunde der alteren Kirche 28. Berlin: Töpelmann. https://doi.org/10.1515/9783110835816.

Bernard, John Henry. 1928. A Critical and Exegetical Commentary on the Gospel according to St. John, International Critical Commentary. Edinburgh: T. \& T. Clark.

Bowman, John. 1975. The Fourth Gospel and the Jews. A Study in R. Ak$i b a$, Esther and the Gospel of John, Pittsburgh Theological Monograph Series 8. Pittsburgh: Pickwick.

Brodie, Thomas L. 1993. The Quest for the Origin of John's Gospel. A Source-Oriented Approach. Oxford: Oxford University Press.

Bruce, Frederick Fyvie. 1983. The Gospel of John. Introduction, Exposition and Notes. Grand Rapids: Eerdmans.

Bruner, Frederick Dale. 2012. The Gospel of John. A Commentary. Grand Rapids: Eerdmans.

Burge, Gary M. 200o. John, The NIV Application Commentary. Grand Rapids: Zondervan.

Burgon, John William. 1896. The Causes of the Corruption of the Traditional Text of the Holy Gospels. London: George Bell and Sons.

Coleman, Beverley Warren. 1970. "The Woman Taken in Adultery. Studies in Texts: 7:53-8:11." Theology 73, No. 603 (September): 409410. https://doi.org/10.1177/0040571X7007300906.

Conybeare, Frederic C. 1895. "On the Last Twelve Verses of St. Mark's Gospel.” The Expositor, Series 5, Vol. 2, No. 6 (December): 401-421. Derrett, John Duncan Martin. 1963. "Law in the New Testament: The Story of the Woman Taken in Adultery." New Testament Studies 10, No. 1 (October): 1-26. https://doi.org/10.1017/Soo28688500002575.

Dietzfelbinger, Christian. 2004². Das Evangelium nach Johannes, t. I: Johannes 1-12, Zürcher Bibelkommentare NT 4/1. Zürich: Theologischer Verlag.

Eisler, Robert. 1923. "Jesus und die ungetreue Braut." Zeitschrift für die neutestamentliche Wissenschaft und die Kunde der alteren Kirche 22, No. 2 (January): 305-307. https://doi.org/10.1515/zntw.1923.22.2.305. 
Gaster, Theodor H. 1958. "A Qumran Reading of Deuteronomy XXXIII 10." Vetus Testamentum 8, No. 2 (April): 217-219. https://doi.org/10.2307/1516089. https://doi.org/10.1163/156853358Xoo178. Genuyt, François. 1986. "Jésus, les scribes et la femme adultère. Analyse sémiotique de l'Evangile de ean (8,1-11)." Sémitique et Bible 42 (Juin): 21-32.

Godet, Frédéric Louis. 1879. Commentary on the Gospel of St. John with a Critical Introduction. Edinburgh: T. \& T. Clark.

Guardiola-Sáenz, Leticia A. 2002. "Border-crossing and its Redemptive Power in John 7,53-8,11: A Cultural Reading of Jesus and the Accused." In John and Postcolonialism. Travel, Space and Power, The Bible and Postcolonialism 7, edited by Musa Dube and Jeffrey Staley, 129-152. London: Sheffield Academic Press.

Guilding, Aileen. 1960. The Fourth Gospel and Jewish Worship. A Study of the Relation of St. John's Gospel to the Ancient Jewish Lectionary System. Oxford Clarendon.

Hengstenberg, Ernst Wilhelm. 1865. Commentary on the Gospel of St John. Edinburg: T. \& T. Clark.

Holmes, Barbara A. / Holmes Susan R. 2003. "Winfield, Sex, Stones, and Power Games: A Woman Caught at the Intersection of Law and Religion (John 7:53-8:11).' In Pregnant Passion: Gender, Sex, and Violence in the Bible, Semeia Studies 44, edited by Cheryl A. KirkDuggan, 143-162. Atlanta: Society of Biblical Literature.

Hoskyns, Edwyn Clement. 1947². The Fourth Gospel. London: Faber \& Faber. Humbert, P. 1919. "Jesus Writing on the Ground (John viii. 6-8)." Expository Times 30, No. 10 (July): 475-476. https://doi.org/10.1177/001452461903001008.

Jeremias, Joachim. 1951. "Zur Geschichtlichkeit des Verhörs Jesu vor dem Hohen Rat." Zeitschrift für die neutestamentliche Wissenschaft, 43 (Jahresband): 145-150. https://doi.org/10.1515/zntw.1951.43.1.145.

Jeremias, Joachim. $1962^{6}$. Die Gleichnisse Jesu. Gottingen: Vandenhoeck \& Ruprecht.

Jovanović, Ljiljana D. 2018. "The Book of Daniel 7-12: Textology and Theology." Ph.D. diss. University of Belgrade. [In Serbian: Јовановић, Љиљана Д. 2018. „Књига пророка Данила 7-12. Текстологија и теологија“. Докторска дисертација, ПБФ Универзитета у Београду]. 
Jovanović, Milivoje M. 1984. Monk Kalist. Belgrade: M. M. Jovanović - R. Zakić. [In Serbian: Јовановић, Миливоје М. 1984. Монах Калисии: роман. Књижевна радионица Растка Закића, књ. 3. Библиотека нових издања, књ. 1. Београд: М. М. Јовановић - Р. Закић].

Keddie, Gordon J. 2007. A Study Commentary on John. Darlington: Evangelical Press.

Keith, Chris. 2008. "Recent and Previous Research on the 'Pericope Adulterae' (John 8,53-8,11)." Currents in Biblical Research 6, No. 3 (June): 377-404. https://doi.org/10.1177/1476993X07084793.

Keith, Chris. 2009a. "The Initial Location of the ,Pericope Adulterae' in Fourfold Tradition." Novum Testamentum 51, No. 3: 209-231. https://doi.org/10.1163/156853608X399142.

Keith, Chris. 2009b. The "Pericope Adulterae", the Gospel of John, and the Literacy of Jesus, New Testament Tools, Studies and Documents 38. Leiden: Brill. https://doi.org/10.1163/ej.9789004173941.i-320.

Keith, Chris. 2013. "On the 'Pericope Adulterae': A Response to J. Keith Elliott." The Journal of Theological Studies 64, No. 2 (October): 432438. https://doi.org/10.1093/jts/flto79.

Kelber, Werner H. 1997. The Oral and the Written Gospel. The Hermeneutics of Speaking and Writing in the Synoptic Tradition: Mark, Paul and Q, Voices in Performance and Text. Bloomington: Indiana University Press.

Knust, Jennifer/ Wasserman, Tommy. 2010. “Ground Accuses Ground: Tracing What Jesus Wrote on the Ground." Harvard Theological Review 103, No. 4 (October): 407-446. https://doi.org/10.1017/Soo17816010000799.

Knust, Jennifer Wright. 2006. "Early Christian Re-Writing and the History of the 'Pericope Adulterae." Journal of Early Christian Studies 14, No. 4 (Winter): 485-536. https://doi.org/10.1353/earl.2007.0009.

Lincoln, Andrew T. 2005. The Gospel according to Saint John, Black's New Testament Commentaries 4. London: Continuum Publishing Corporation.

Lindars, Barnabas, ed. 1988. Law and Religion. Essays on the Place of the Law in Israel and Early Christianity. Cambridge: James Clarke.

Lindars, Barnabas. 1972. The Gospel of John, New Century Bible. London: Oliphants.

Malina, Bruce J. / Rohrbaugh, Richard L. 1998. Social-Science Commentary on the Gospel of John. Minneapolis: Fortress Press. 
Manicardi, Luciano. 2001. "'Gesù scriveva per terra' (Gv 8,6.8)." Parola, Spirito e Vita 43, No. 1: 139-162.

Manson, Thomas Walter. 1953. "The Pericope de Adultera (Joh 7,538,11). A Footnote to the Article by Professor Jeremias ZNW 43 (1950/51) 145-150." Zeitschrift für die neutestamentliche Wissenschaft 44 (Jahresband): 255-256. https://doi.org/10.1515/zntw.1953.44.1.255.

Margoliouth, D. S. 1919. "Jesus Writing on the Ground." Expository Times 31, No. 1 (October): 38. https://doi.org/10.1177/001452461903100107.

Matveyevsky, Pavel A. 189o. Evangelical History. Saint Petersburg. [In Russian: Матвеевский, Павел Алексеевич. 1890. Евангельская история. Санкт Петерсбург].

McDonald, J. Ian H. 1995. "The So-Called 'Pericope de Adultera"' New Testament Studies 41, No. 3 (July): 415-427. https://doi.org/10.1017/Soo28688500021561.

Metzger, Bruce M. $\mathbf{2 0 0 1}^{2}$. A Textual Commentary on the Greek New Testament. Stuttgart: Deutsche Bibelgesellschaft.

Meyer, Frederick Brotherton. 1970. Gospel of John. The Life and Light of Man, Love to the Utmost. Fort Washington: Christian Literature Crusade.

Michaels, J. Ramsey. 2010. The Gospel of John, The New International Commentary on the New Testament. Grand Rapids: Eerdmans.

Minear, Paul S. 1991. "Writing on the Ground. The Puzzle in John 8:1-11." Horizons in Biblical Theology 13, No. 1 (January): 23-37. https://doi.org/10.1163/187122091X00036.

Moloney, Francis J. 1998. The Gospel of John, Sacra Pagina 4. Collegeville: Liturgical Press.

Morrice, W. 1997. Hidden Sayings of Jesus. Words Attributed to Jesus Outside the Four Gospels. Peabody: Hendrickson.

Neyrey, J. H. 2007. The Gospel of John, The New Cambridge Bible Commentary. Cambridge: Cambridge University Press.

O’Day, Gail R. 1992. "John 7:53-8:11: A Study in Misreading." Journal of Biblical Literature 111, No. 4 (Winter): 631-640. https://doi.org/10.2307/3267436.

O'Day, Gail R. 1996. The Gospel of John. Introduction, Commentary, and Reflections. Nashville: Abingdon.

Power, E. 1921. "Writing on the Ground (Joh. 8, 6. 8)." Biblica 2, No. 1: 54-57. JSTOR, https://www.jstor.org/stable/42615601. 
Ridderbos, H. N. 1997. The Gospel according to John. A Theological Commentary. Grand Rapids: Eerdmans.

Robinson, Maurice A. / Pierpont, William G., eds. 2005. The New Testament in the Original Greek. Southborough: Chilton Book.

Rousseau, François. 1978. "La femme adultère: Structure de Jn 7,53-8,11." Biblica 59, No. 4: 463-480. JSTOR, https://www.jstor.org/stable/42706751.

Sanders, James A. 1990. “Nor Do I.... A Canonical Reading of the Challenge to Jesus in John 8." In The Conversation Continues. Studies in Paul and John in Honor of J. Louis Martyn, edited by Robert T. Fortna and Beverly R. Gaventa, 337-347. Nashville: Abingdon Press.

Schnackenburg, Rudolf. 1990. The Gospel according to St. John. New York: Crossroad.

Schnelle, Udo. 20094. Das Evangelium nach Johannes, Theologischer Handkommentar zum Neuen Testament 4. Leipzig: Evangelische Verlagsanstalt.

Schöndorf, Harald. 1996. "Jesus schreibt mit dem Finger auf die Erde: Joh 8,6b.8." Biblische Zeitschrift 40, No. 1, 91-93. https://doi.org/10.1163/25890468-04001007.

Schwarz, O. 1982. "Jer. 17,13 als möglicher alttestamentlicher Hintergrund zu Jo. 8,6.8." In Von Kanaan bis Kerala. Festschrift für Prof. Mag. Dr. Dr. J. P. M. van der Ploet O.P. zur Vollendung des siebzigsten Lebensjahres am 4. Juli 1979, Alter Orient und Altes Testament 211, edited by W. C. Delsman et al., 239-256. Kevelaer: Butzon \& Bercker / Neukirchen-Vluyn: Neukirchner.

Seeley, John Robert. 1866. Ecce Homo. A Survey of the Life and Work of Jesus Christ. Boston: Roberts Brothers.

Staley, Jeffrey A. 2005. "Reading 'This Woman' Back into John 7:1-8:59: Liar Liar and the 'Pericope Adulterae' in Intertextual Tango." In Those Outside: Noncanonical Readings of the Canonical Gospels, edited by George Aichele and Richard G. Walsh, 85-107. London: T. \& T. Clark.

Strachan, Robert Harvey. 1941. The Fourth Gospel. Its Significance and Environment. London: SCM Press.

Strack, Hermann L. / Billerbeck, Paul. 1924. Kommentar zum Neuen Testament aus Talmud und Midrasch, t. II: Das Evangelium nach Markus, Lukas und Johannes und die Apostelgeschichte. München: Oskar Beck. https://doi.org/10.17104/9783406757020-I. 
Tatalović, Vladan. 2019. Basics of Exegesis of the Writings of St. John the Theologian. Belgrade: Institute for Theological Research - Biblical Institute. [In Serbian: Таталовић, Владан. 2019. Основи еізеіеезе сиичса Светиой Јована Боїослова. Београд: Институт за теолошка истраживања - Библијски институт].

Temple, William. 1945. Readings in St. John's Gospel. London: Macmillan. Theobald, Michael. 2009. Das Evangelium nach Johannes, Kapitel 1-12, Regensburger Neues Testament. Regensburg: Pustet.

Toensing, H. J. 2003. "Divine Intervention or Divine Intrusion? Jesus and the Adulteress in John's Gospel." In A Feminist Companion to John, t. I, Feminist Commentaries 4, edited by Amy-Jill Levine and Marianne Blickenstaff, 159-172. London: Sheffield Academic Press.

Velimirovich, Bishop Nicholai. 2016. Collected Works, Vol. VIII. Šabac: Monastery of St Nicholas. [In Serbian: Велимировић, Еп. Николај. 2016. Сабрана gела, књ. VIII. Шабац: Манастир Св. Николаја - Соко].

Vermes, G. 1958. "The Torah is a Light." Vetus Testamentum 8, No. 4 (October): 436-438. https://doi.org/10.2307/1516158. https://doi.org/10.1163/156853358Xo0484.

Watson, Alan. 1999. "Jesus and the Adulteress." Biblica 80, No. 1: 100108. JSTOR, https://www.jstor.org/stable/42614145.

Wensinck, Arent Jan. 1933. “John VIII. 6,8." In Amicitiae Corolla. A Volume of Essays Presented to James Rendel Harris, D. Litt. on the Occasion of His Eightieth Birthday, edited by Herbert G. Wood, 300-302. London: University of London Press.

Werchmestier, Otto Karl. 1963. Der Deckel des Codex Aureus von St. Emmermam. Ein Goldschmiedewerk des 9. Jahrhunderts. Baden-Baden — Strasbourg: Heitz.

Westcott, Brooke Foss. 1882. The Gospel according to St. John. The Authorized Version with Introduction and Notes. London: John Murray.

Whitacre R. A. 1999. John. Downers Grove: InterVarsity.

Wilckens, U. $\mathbf{2 0 0 0}^{18}$. Das Evangelium nach Johannes, Das Neue Testament Deutsch 4. Gottingen: Vandenhoeck \& Ruprecht.

Young, Brad H. 1995. "Save the Adulteress': Ancient Jewish Responsa in the Gospels?" New Testament Studies 41, No. 1 (January): 59-70. https://doi.org/10.1017/Soo28688500022943. 